\title{
Mutation analysis of BRAF and KIT in circulating melanoma cells at the single cell level
}

\author{
K Sakaizawa', Y Goto', Y Kiniwa', A Uchiyama', K Harada², S Shimada ${ }^{2}$, T Saida', S Ferrone ${ }^{3}$, M Takata', \\ H Uhara' and R Okuyama*,I \\ 'Department of Dermatology, Shinshu University School of Medicine, 3-I - I Asahi, Matsumoto 390-862 I, Japan; 'Department of Dermatology, \\ University of Yamanashi School of Medicine, 1110 Shimokawato, Chuo 409-3898, Japan; ${ }^{3}$ Departments of Surgery, Immunology and Pathology, \\ University of Pittsburgh Cancer Institute, 5117 Center Avenue Suite 2.26d, Pittsburgh, PA 15213, USA
}

\begin{abstract}
BACKGROUND: The availability of molecular-targeted therapies for the treatment of melanoma has emphasised the need to identify mutations in target genes such as BRAF and KIT. Circulating tumour cells (CTC) are present in the peripheral blood of a significant proportion of cancer patients.

METHODS: High molecular weight melanoma-associated antigen (HMW-MAA) was used to isolate melanoma cells from peripheral blood as it is selectively expressed at high levels on melanomas. The HMW-MAA-positive cells were isolated using immunomagnetic beads. After removing CD45 ${ }^{+}$cells, CTC were identified by staining with MART-I - and gp I00-specific antibodies (HMW-MAA ${ }^{+}$, $\left.\mathrm{CD}^{-} 5^{-}, \mathrm{MART}-\mathrm{I} / \mathrm{gp} / 00^{+}\right)$. Single, isolated CTC were then subjected to BRAF and KIT mutational analysis.

RESULTS: CTC (HMW-MAA ${ }^{+}, \mathrm{CD}^{-} 5^{-}, \mathrm{MART}-\mathrm{I} / \mathrm{gp} I 00^{+}$) were isolated from the blood of II patients and BRAF and KIT were sequenced in nine and four patients, respectively. The BRAF sequences identified in the CTC were inconsistent with those identified in autologous melanoma tumours in three patients and the KIT sequences were inconsistent in three patients. In addition, polyclonal BRAF mutations were identified in one patient and concomitant mutations in BRAF and KIT were identified in another patient. CONCLUSION: Melanoma cells show clonal heterogeneity. Therefore, CTC genotyping may be crucial for successful molecular-targeted therapy.

British Journal of Cancer (2012) 1 06, 939-946. doi:I0.1038/bjc.2012.12 www.bjcancer.com

Published online 26 January 2012

(c) 2012 Cancer Research UK
\end{abstract}

Keywords: melanoma; circulating tumour cells; oncogene mutations; BRAF; KIT; HMW-MAA

Therapies that target specific molecules markedly inhibit cancer growth in several malignancies, and provide valuable strategies for the treatment of advanced melanoma (Romano et al, 2011). In recent years, BRAF and KIT have become established therapeutic targets in melanoma patients showing activating mutations in these oncogenes. Significant clinical benefits have been achieved using the RAF kinase inhibitor, vemurafenib, to treat melanomas showing BRAF mutations and the receptor protein kinase inhibitor, imatinib, to treat melanomas showing KIT mutations (Flaherty et al, 2010; Carvajal et al, 2011; Chapman et al, 2011; Guo et al, 2011). Somatic missense activating mutations in BRAF have been identified in about $60 \%$ of primary melanoma lesions (Davies et al, 2002), and KIT mutations in $14 \%$ and $18 \%$ of acral lentiginous and mucosal melanomas, respectively (Woodman and Davies, 2010). However, it is crucial that genetic mutations present in the melanoma lesions are identified if we are to design tailormade therapies for individual patients. The tumour genotypes that determine the selection of molecular-targeted therapies are usually identified in primary tumours; however, primary tumours are not always representative of metastases. For example, Terheyden et al (2010) reported the case of a melanoma patient

*Correspondence: Dr R Okuyama; E-mail: rokuyama@shinshu-u.ac.jp Received 18 October 201 I; revised 4 January 2012; accepted 9 January 2012; published online 26 January 2012 with a primary lesion and lymph node metastases that showed a wild-type KIT genotype, but with lung metastasis harbouring a KIT ${ }^{559 \mathrm{~A}}$ mutation.

Circulating tumour cells (CTC) have been identified in peripheral blood from a significant proportion of patients with recurrent disease, and may still be detectable following removal of the primary tumour (Allard et al, 2004; Mocellin et al, 2006). It may be a source of valuable information because they can be obtained via routine blood sampling, they provide real-time information about a patient's current disease state, and their features may mirror those of recurrent tumours. However, CTC from melanoma patients have only been characterised to a limited extent. This limitation reflects, at least in part, difficulties in isolating these rare cells from the many circulating blood cells. Recently, melanoma cells were isolated from melanoma patients using immunomagnetic beads coated with antibodies specific for chondroitin sulphate proteoglycan (CSPG) 4 (Ulmer et al, 2004; Kitago et al, 2009; Suesskind et al, 2011). This tumour antigen, also known as high molecular weight melanoma-associated antigen (HMW-MAA), can be used to identify and isolate CTC from peripheral blood because it is expressed on the melanoma cell membrane in $>85 \%$ of primary and metastatic melanoma lesions (Campoli et al, 2004). High affinity CSPG 4-specific antibodies are available, and the corresponding epitopes are not detectable on normal blood cells. 
Therefore, the aim of the present study was to isolate intact CTC from peripheral blood using a three-step purification procedure incorporating positive selection with a pool of three HMW-MAAspecific monoclonal antibodies (mAbs) followed by negative selection with a CD45-specific mAb. The purity of the isolated CTC was monitored according to the expression of HMW-MAA and MART-1/gp100 (melanoma markers), and lack of CD45 expression (a haematopoietic cell marker). BRAF and KIT mutations in CTC were then examined at the single cell level and the genotypes compared with those of the primary and metastatic lesions.

\section{MATERIALS AND METHODS}

\section{Melanoma cell lines, reagents, mAbs, and clinical specimens}

Detailed procedures and patient information are described in Supplementary Information.

\section{Isolation of melanoma cells from peripheral blood}

Heparinised blood samples $(5 \mathrm{ml})$ were treated with $\mathrm{RBC}$ lysis solution (Qiagen, Germantown, MD, USA), after which $>4 \times 10^{6}$ mononuclear cells were obtained. Circulating tumour cells were isolated from the mononucleated cells using HMW-MAA-specific mAb-coated immunomagnetic beads (Dynabeads CELLection Pan Mouse IgG Kit; Invitrogen, Oslo, Norway) according to manufacturer's instructions with minor modifications. Melanoma cells were labelled with $\mathrm{mAb}$ before capture using immunomagnetic beads because previous work showed that this indirect technique is better than direct techniques for separating melanoma cells from the blood (Kitago et al, 2009). In brief, $6 \mu \mathrm{l}$ of a cocktail containing HMW-MAA-specific mAbs 763.74, VF1-TP41.2, and VT80.12 (final concentration of each mAb: $33 \mu \mathrm{g} \mathrm{ml}^{-1}$ ) was added to $4 \times 10^{6}$ cells suspended in $294 \mu \mathrm{l}$ phosphate-buffered saline (PBS) containing $0.1 \%$ bovine serum albumin (BSA). Samples were incubated with rotation at 22 r.p.m. at room temperature (Invitrogen) for $20 \mathrm{~min}$. After washing with $\mathrm{PBS} / 0.1 \% \mathrm{BSA}$, the samples were mixed with $25 \mu \mathrm{l}$ of immunomagnetic beads (antimouse IgG-coated), which included $1 \times 10^{7}$ beads. The mixtures were incubated with rotation at 22 r.p.m. for an additional $30 \mathrm{~min}$. Samples were then placed in a DYNAL MPC-S magnetic device (Invitrogen) for $2 \mathrm{~min}$. Following removal of the fluid by careful pipetting and washing twice with $\mathrm{PBS} / 0.1 \%$ BSA, cells were released from the beads by incubation with releasing buffer (Invitrogen) for $20 \mathrm{~min}$ on a mixing device. The mixture was then vigorously pipetted and replaced in the DYNAL MPC-S magnetic device for $2 \mathrm{~min}$ to isolate HMW-MAA ${ }^{+}$cells. Human CD45specific $\mathrm{mAb}$-coated immunomagnetic beads (Invitrogen) were then used to remove contaminating white blood cells. After incubation and washing, the $\mathrm{HMW}-\mathrm{MAA}^{+}, \mathrm{CD}^{-} 5^{-}$cell population was collected. The $\mathrm{HMW}-\mathrm{MAA}^{+}, \mathrm{CD}^{-} 5^{-}$cells were then smeared onto a silane-coated glass slide (Dako, Carpinteria, CA, USA) and stained (EnVision System; Dako) with a cocktail of MART-1 and gp100 antibodies. The stained cells were then subjected to laser-capture microdissection using a PALM-MB microdissection system (PALM Microlaser Technologies, Bernried, Germany) and scored as positive when a clear signal was observed

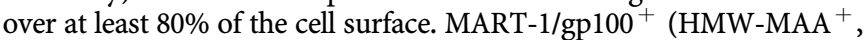
CD45 ${ }^{-}$, MART-1/gp $100^{+}$) cells were then isolated individually and placed separately in adhesive tubes (Meiwafosis, Tokyo, Japan). These cells were referred to as CTC.

\section{DNA extraction}

For extraction of genomic DNA from single CTC, $3 \mu \mathrm{l}$ of lysis buffer (10 mM Tris - $\mathrm{HCl}(\mathrm{pH} 8.3), 50 \mathrm{~mm} \mathrm{KCl}, 4 \mathrm{mg} \mathrm{ml}^{-1}$ proteinase K (Roche Diagnostics, Basel, Switzerland), and 3\% Tween-20) was added to each tube. The tubes were subsequently vortexed. After centrifugation, each CTC was incubated for $16 \mathrm{~h}$ at $50^{\circ} \mathrm{C}$, after which proteinase $\mathrm{K}$ was heat inactivated at $95^{\circ} \mathrm{C}$ for $10 \mathrm{~min}$. As a negative control, empty tubes were incubated with lysis buffer. In addition, DNA was extracted from formalin-fixed, paraffinembedded surgically resected tumour tissues. Three $6-\mu \mathrm{m}$ sections were cut from paraffin-embedded tissue blocks with a sterile microtome blade and mounted on glass slides. After deparaffinisation, tissues stained with methylene blue were dissected manually on an inverted microscope to select melanoma lesions. The dissected tissues were placed in sterile tubes and digested with a mixture containing $20 \mu \mathrm{l}$ of proteinase $\mathrm{K}$ and $180 \mu \mathrm{l}$ of $25 \mathrm{~mm}$ Tris $\mathrm{HCl}$ at $37^{\circ} \mathrm{C}$ for $12 \mathrm{~h}$. After completion of the incubation, proteinase $\mathrm{K}$ was heat inactivated at $80^{\circ} \mathrm{C}$ for $20 \mathrm{~min}$.

\section{Analysis of BRAF and KIT mutations}

Primers were designed to amplify exon 15 of $B R A F$ and exons 11, 13 , and 17 of KIT, all of which include mutational hot spots (Davies et al, 2002; Woodman and Davies, 2010). Exon 15 of BRAF was amplified using a hemi-nested PCR, and exons 11, 13, and 17 of KIT were amplified using nested PCR (Buttner et al, 1998; Hofmann et al, 2009; Lin et al, 2009). The primer sequences and PCR cycling conditions are shown in Supplementary Table S1. The first PCR amplification for exon 15 of $B R A F$ was conducted in a $20-\mu$ reaction volume containing Ex Taq buffer with $2.0 \mathrm{~mm}$ $\mathrm{MgCl}_{2}, 0.2 \mathrm{~mm}$ dNTP mixture, $0.3 \mu \mathrm{M}$ primers, $0.5 \mathrm{U}$ of Ex Taq (Takara, Shiga, Japan), and $2 \mu \mathrm{l}$ of DNA template. Then, $0.2 \mu \mathrm{l}$ of the first PCR amplification product was used as template for the second PCR amplification, which was conducted in a $20-\mu 1$ reaction volume. KIT exons were amplified in singleplex reactions. Nested PCR for KIT exons, both the first and second PCR amplifications, was conducted in $20 \mu \mathrm{l}$ reaction volumes including $2 \mu \mathrm{l}$ of DNA template. The PCR amplification was performed in iCycler (Bio-Rad Laboratories, Hercules, CA, USA). After confirming the size of the PCR products on agarose gels, the products were purified using the QIAquick PCR Purification Kit (Qiagen). Direct sequencing was performed to identify mutations within exon 15 of $B R A F$ and exons 11,13 , and 17 of KIT. The primer used for the forward reading reaction of $B R A F$ exon 15 was $5^{\prime}$-TCATAATGCTTGCTCTGATAGGA-3'. The primers used for the forward reading reaction of KIT exons 11,13 , and 17 were the same as the forward inner primers used for nested PCR. Each sequencing reaction was carried out using the BigDye Terminator v3.1 cycle sequencing kit (Applied Biosystems, Foster City, CA, USA) in a $20-\mu l$ volume containing purified PCR product and sequence primer. The temperature for the sequencing reaction was $96^{\circ} \mathrm{C}$ for $1 \mathrm{~min}$, which was followed by 25 cycles at $96^{\circ} \mathrm{C}$ for $10 \mathrm{~s}, 54^{\circ} \mathrm{C}$ for $5 \mathrm{~s}$, and $60^{\circ} \mathrm{C}$ for $4 \mathrm{~min}$. The reaction products were precipitated with $95 \%$ ethanol and $3 \mathrm{~mm}$ sodium acetate, washed with $70 \%$ ethanol, resuspended in $20 \mu \mathrm{l} \mathrm{Hi-Di} \mathrm{formamide} \mathrm{and}$ loaded onto an ABI PRISM 3100 Genetic Analyzer (Applied Biosystems). The analysis was conducted following the accepted PCR guidelines (Bustin et al, 2009).

\section{RESULTS}

\section{Melanoma cell separation in an in-vitro model experiment}

To establish the optimal conditions for isolating CTC from peripheral blood, cultured melanoma cells were mixed with peripheral blood and isolated using immunomagnetic beads. Briefly, the melanoma cell lines $888 \mathrm{mel}$, 928mel, or MMG1, which express HMW-MAA and MART-1/gp100, were spiked into healthy human peripheral blood samples at concentrations ranging from $1 \times 10^{2}$ to $1 \times 10^{5}$ cells per $5 \mathrm{ml}$ blood. The mixtures were sequentially stained with mAbs specific for HMW-MAA- and 
CD45 and fractionated using immunomagnetic beads. A mixture of $m A b s$ that recognise distinct and spatially distant epitopes on HMW-MAA was used to minimise false-negative results caused by differential expression of HMW-MAA epitopes, and to increase the detection level of the system (Kitago et al, 2009). To confirm that the isolated $\mathrm{HMW}-\mathrm{MAA}^{+}$, CD45 ${ }^{-}$cells were melanoma cells, the cells were stained with MART-1- and gp100-specific mAbs and observed under a microscope (Figure 1A). Isolated HMW-MAA ${ }^{+}$, CD $45^{-}$, MART-1/gp $100^{+}$cells comprised $1-24 \%$ of the melanoma cells initially mixed with the peripheral blood (Table 1 ). The three melanoma cell lines showed different recovery rates. The expression level of HMW-MAA was measured by reverse transcription PCR (RT - PCR) and flow cytometry, and that of MART-1/gp100 by immunostaining. Results showed no correlation between the recovery rates and the level of HMW-MAA or MART-1/gp100 (data not shown).

The possibility that mutant alleles may 'drop-out' during PCR, a known problem when using single cells, was assessed (Piyamongkol et al, 2003). The BRAF mutation was analysed in single $\mathrm{HMW}-\mathrm{MAA}^{+}, \mathrm{CD}^{-} 5^{-}$, MART-1/gp $100^{+}$cells isolated from blood mixed with $928 \mathrm{mel}$ cells, which harbour the heterozygous $B R A F^{V 600 E}$ mutation (Lin et al, 2009). DNA was extracted from each cell and $B R A F$ exon 15 , which is the most common mutation site (Platz et al, 2008), was sequenced in each cell individually. The BRAF $F^{V 60 E}$ mutation was detected in $88.9 \%$ of the isolated $928 \mathrm{mel}$ cells ( 48 of 54 cells sequenced). The dropout of mutant alleles during single-cell PCR is likely to be a relatively rare event; a previous study using a melanoma cell line showed that the phenomenon occurs at a frequency of only $2-14 \%$ (1-7 out of 50 single melanoma cells) (Lin et al, 2009). Thus, in this in-vitro model experiment, the BRAF mutation was successfully detected in individual melanoma cells isolated from peripheral blood.

\section{CTC separation from the peripheral blood of melanoma patients}

Next, CTC were isolated from the peripheral blood of 11 patients with stage IIIC/IV melanoma (Table 2), all of which expressed HMWMAA and MART-1/gp100, as detected by immunohistochemical analysis. Peripheral blood was incubated with the mAb cocktail and magnetic beads as described in the previous section. The HMW-MAA ${ }^{+}, \mathrm{CD}_{4} 5^{-}$cells were isolated and the cellular phenotype was confirmed by MART-1/gp100 expression. The HMW-MAA ${ }^{+}, \mathrm{CD}^{-} 5^{-}$, MART-1/gp $100^{+}$cells were detected in all the patients. The isolated cells were larger and showed an abnormal morphology (Figure 1B). The yield of CTC from $5 \mathrm{ml}$ of blood ranged from 1 to 20 (Table 2). Because MART-1/gp $100^{+}$ cells could be identified microscopically, contamination by nonmelanoma cells non-specifically bound to the immunomagnetic beads was unlikely. As controls, peripheral blood samples obtained from healthy individuals were included in every experiment. No HMW-MAA ${ }^{+}, \mathrm{CD}_{4} 5^{-}$, MART-1/gp $100^{+}$CTC were isolated from the peripheral blood of $>50$ healthy donors.

\section{$B R A F$ mutations in CTC from the peripheral blood of melanoma patients}

CTC were captured individually. BRAF exon 15 was amplified from single CTC from 9 out of 11 melanoma patients and $B R A F$ exon 15 sequences were obtained from 14 individual CTC (Table 3). Single CTC PCR occasionally failed; the success rate of PCR amplification from single CTC ranged from $20 \%$ to $100 \%$. In three cases in which primary melanomas showed $B R A F^{\mathrm{V} 600 \mathrm{E}}$ mutation, CTC shared a similar BRAF genotype with the primary tumours (Nos. 4, 5, and 6; Table 3). By contrast, lymph node metastases from patient No. 9 showed a $B R A F^{\mathrm{V} 600 \mathrm{E}}$ mutation while two CTC showed wild-type BRAF. This result should be interpreted with caution because of the possibility of mutant allele drop-out in CTC; however, that phenomenon is likely to be relatively rare, as discussed earlier. Interestingly, CTC from patient No. 5 showed a $B R A F^{\mathrm{V} 600 \mathrm{~K}}$ mutation and a wild-type sequence in addition to the $B R A F^{\mathrm{V} 600 \mathrm{E}}$ mutation (which was also identified in the primary tumour and lymph node metastasis; Figure 2A). This suggests clonal heterogeneity in terms of $B R A F$ mutations during melanoma progression.

The BRAF genotype in metastases of patient Nos. 5, 6, and 9 was assessed further because these three cases showed a mismatched $B R A F$ genotype between metastasis and CTC. Clusters of 30-50
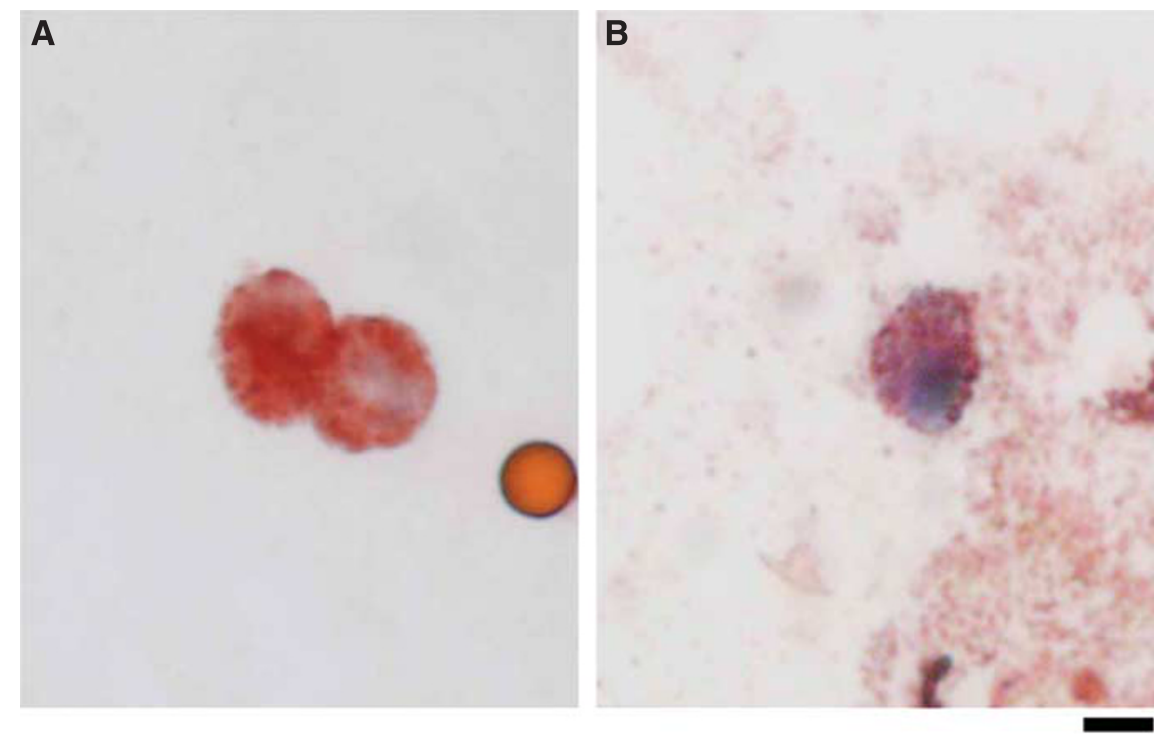

Figure I Melanoma cells isolated from peripheral blood. HMW-MAA ${ }^{+}, \mathrm{CD}_{4} 5^{-}$cells were isolated on immunomagnetic beads and stained with a mixture of MART-I and gp I00 antibodies. MART-I/gp I00-positive cells stained brownish-red with aminoethylcarbazole. (A) Spiked MMG-I cells isolated from the peripheral blood of a healthy individual. The small light-brown spheroid is an immunomagnetic bead. (B) CTC detected in a patient with melanoma. Scar bar: $5 \mu \mathrm{m}$. 
melanoma cells were microdissected from different areas within metastatic lesions to detect minor populations of tumour cells, since conventional sequencing usually detects genetic mutations at a rate of $>20 \%$ (Ellison et al, 2010). The microdissected lesions showed both $B R A F^{\mathrm{V} 600 \mathrm{E}}$ and wild-type $B R A F$ in Nos. 5 and 6 , but not in No. 9 (Supplementary Table S2). Although the macrodissected lesions showed $B R A F^{\mathrm{V} 600 \mathrm{E}}$ in No. 5 and wild type in No. 6, some microdissected samples showed different genotypes (wild type in No. 5 and $B R A F^{\mathrm{V} 600 \mathrm{E}}$ in No. 6), suggesting that a substantial number of cells harboured different $B R A F$ genotypes. Metastatic lesions may occasionally include heterogeneous tumour cells. The $B R A F^{\mathrm{V} 600 \mathrm{~K}}$ mutation was not detected in the metastasis of No. 5 nor was wild-type BRAF in that of No. 9. These data

Table I Recovery of melanoma cells mixed with peripheral blood

Observed cell count

No. of melanoma cells mixed in $5 \mathrm{ml}$ of peripheral

\begin{tabular}{lccc} 
blood & $\mathbf{8 8 8 m e l}$ & $\mathbf{9 2 8} \mathbf{m e l}$ & MMG I \\
\hline $10^{5}$ & $7600(7.6 \%)$ & $2420(2.4 \%)$ & $1920(1.9 \%)$ \\
$10^{4}$ & $1910(19.1 \%)$ & $260(2.6 \%)$ & $162(1.6 \%)$ \\
$10^{3}$ & $140(14 \%)$ & $20(2 \%)$ & $19(1.9 \%)$ \\
$10^{2}$ & $24(24 \%)$ & $1(1 \%)$ & $3(3 \%)$ \\
0 & $0(0 \%)$ & $0(0 \%)$ & $0(0 \%)$
\end{tabular}

Results represent the average of two independent experiments. suggest that CTC with mismatched genotypes may be derived from minor populations within metastatic lesions.

\section{KIT mutations in CTC isolated from the peripheral blood of melanoma patients}

The sequences within three exons (exons 11, 13, and 17) of KIT, which are reported to harbour mutations (Woodman and Davies, 2010), were also examined. The PCR amplification success rate ranged from $0 \%$ to $50 \%$ (Table 3). To optimise PCR conditions from single cells, several conditions were tested, including primers, enzymes, and buffers; however, the success rate did not improve sufficiently. KIT genotypes were analysed in only four patients (Table 3). Unlike BRAF genotypes, KIT genotypes were poorly matched between primary tumours, metastases, and CTC (Table 3 ). The primary tumours from two patients (Nos. 1 and 10) showed KIT mutations, but no KIT mutations were detectable in lymph node metastases and/or CTC. However, KIT mutations were detected in either metastases or CTC in patient Nos. 4 and 11, whereas the primary lesions showed wild-type KIT. It is interesting to note that patient No. 4 showed not only a $K I T^{\mathrm{V} 560 \mathrm{G}}$ mutation in CTC, but also a $B R A F^{\mathrm{V} 600 \mathrm{E}}$ mutation in the primary tumour, as well as in another CTC (Figure 2B); this is unusual because mutations in BRAF and KIT are thought to be mutually exclusive (Curtin et al, 2006; Carvajal et al, 2011). In addition, KIT ${ }^{\mathrm{V} 560 \mathrm{G}}$ has not been reported in melanomas, but is prevalent in gastrointestinal stromal tumours and mastocytosis (Tarn et al, 2005; Lanternier et al, 2008).

Table 2 Clinical characteristics of the II melanoma patients

\begin{tabular}{ccclclc} 
No. & Sex & Age (years) & Histopathological type & AJCC stage & Metastatic sites & No. of CTC in $\mathbf{5}$ ml of PB \\
\hline I & M & 54 & Mucosal & IV & Lymph nodes, lung, brain, spinal cord & $2-5$ \\
2 & F & 78 & Mucosal & IV & Lymph nodes, lung, liver \\
3 & M & 67 & Mucosal & IIC & Lymph nodes \\
4 & F & 68 & Mucosal & IV & Lymph nodes, lung \\
5 & F & 64 & Non-CSD & IV & Lymph nodes, lung, liver, skin & 2 \\
6 & M & 61 & Non-CSD & IV & Lymph nodes, lung, brain, skin & I-5 \\
7 & F & 62 & Non-CSD & IV & Lymph nodes, lung, peritoneum & I-20 \\
8 & M & 73 & Non-CSD & IV & Lymph nodes, digestive tract, pleura, abdominal cavity, skin \\
9 & M & 69 & Unknown & IV & Lymph nodes, liver, digestive tract, bone, adrenal, skin \\
I0 & F & 62 & Acral & IIIC & Lymph nodes \\
II & M & 84 & Acral & IV & Lymph nodes, lung, brain & I \\
\hline
\end{tabular}

Abbreviations: $\mathrm{CTC}=$ circulating tumour cells; non-CSD = melanoma on non-chronic sun-damaged skin; $\mathrm{PB}=$ peripheral blood

Table 3 Genotypes of BRAF and KIT in melanoma patients

BRAF (exon I5)

\begin{tabular}{|c|c|c|c|}
\hline \multirow[b]{2}{*}{ No. } & \multicolumn{2}{|c|}{ Tissue } & \multirow[t]{2}{*}{ Single CTC } \\
\hline & Primary & Metastasis & \\
\hline । & Wild type & Wild type & Wild type (I) \\
\hline 2 & Wild type & NA & Wild type (I) \\
\hline 3 & Wild type & NA & Wild type (I) \\
\hline 4 & V600E & UR & $\operatorname{V600E}(1)$ \\
\hline 5 & V600E & V600E & V600E (I), V600K (I), wild type (I) \\
\hline 6 & V600E & Wild type & V600E (3) \\
\hline 7 & Wild type & Wild type & Wild type (I) \\
\hline 8 & Wild type & Wild type & Wild type (I) \\
\hline 9 & NA & V600E & Wild type (2) \\
\hline 10 & Wild type & Wild type & NE \\
\hline | | & Wild type & Wild type & NE \\
\hline
\end{tabular}

KIT (exons II, 13, and I7)

\begin{tabular}{|c|c|c|c|}
\hline \multicolumn{2}{|c|}{ Tissue } & \multicolumn{2}{|c|}{ Single CTC } \\
\hline Primary & Metastasis & $\begin{array}{l}\text { No. of cells } \\
\text { sequenced }\end{array}$ & $\begin{array}{l}\text { Success } \\
\text { rate of } P C R\end{array}$ \\
\hline D820Y & Wild type & UR & $0 / 3$ \\
\hline Wild type & NA & UR & $0 / 1$ \\
\hline Wild type & NA & NE & NE \\
\hline Wild type & UR & V560G (I) & $1 / 2$ \\
\hline Wild type & Wild type & Wild type (I) & $1 / 3$ \\
\hline Wild type & Wild type & NE & NE \\
\hline UR & Wild type & $\mathrm{NE}$ & NE \\
\hline Wild type & Wild type & NE & NE \\
\hline NA & Wild type & NE & NE \\
\hline N822Y & Wild type & Wild type (I) & $1 / 6$ \\
\hline Wild type & N822Y & Wild type (I) & $1 / 2$ \\
\hline
\end{tabular}

Abbreviations: $C T C=$ circulating tumour cells; $N A=$ tissues not available; $N E=$ not examined; UR = sequence unreadable due to PCR failure. 
A

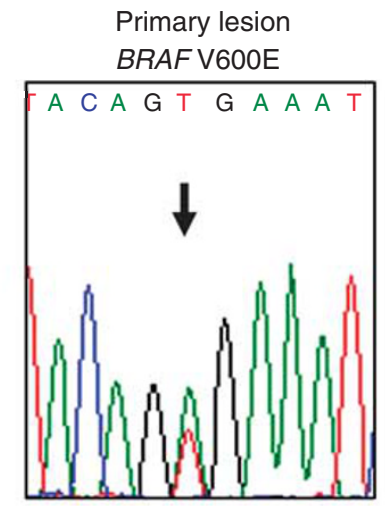

CTC

BRAF V600E

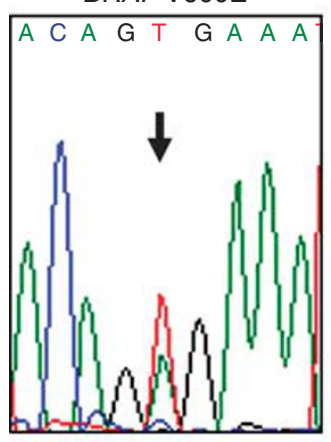

CTC

BRAF V $600 \mathrm{~K}$

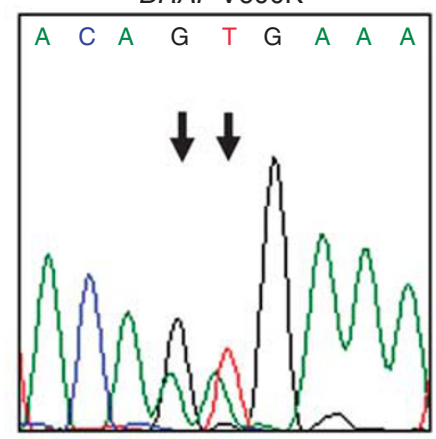

CTC

$B R A F$ wild type

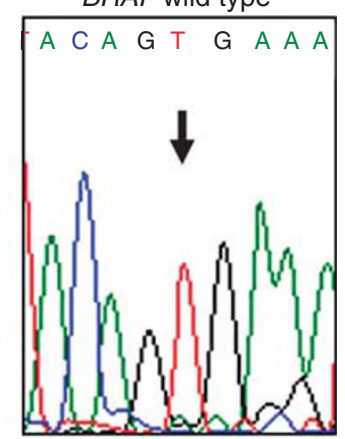

B

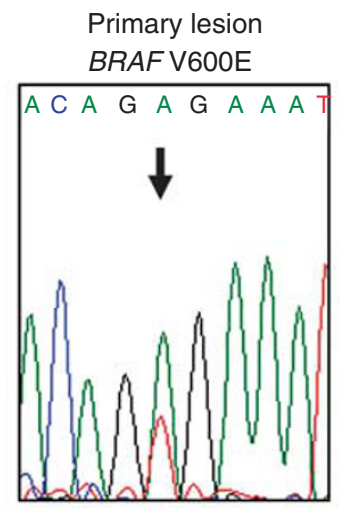

Primary lesion

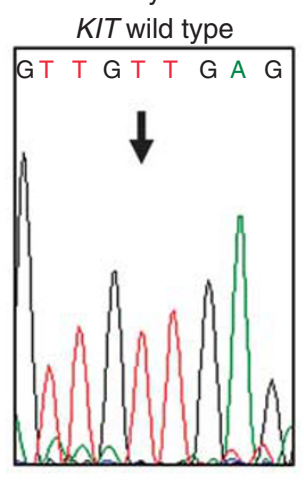

CTC

BRAF V600E

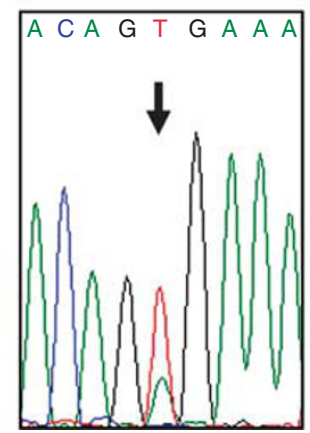

KIT V560G

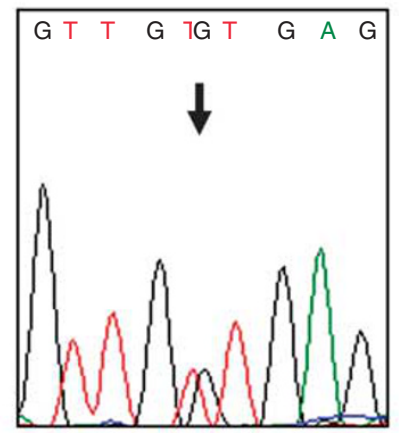

Figure 2 BRAF and KIT mutations detected in CTC isolated from melanoma patients. (A) Polyclonal BRAF mutations detected in CTC from patient No. 5. Primary and metastatic lesions showed $B R A F^{\vee 600 E}$ (upper). Two CTC showed BRAF ${ }^{\mathrm{V} 600 \mathrm{E}}$ and $B R A F^{\vee 600 \mathrm{~K}}$ mutations, respectively (lower left and middle), and another CTC possessed wild-type BRAF (lower right). (B) Concomitant detection of BRAF ${ }^{\mathrm{V} 600 \mathrm{E}}$ (lower left) and KIT ${ }^{560 G}$ (lower right) mutations in CTC obtained from patient No. 4. The primary lesion showed $B R A F^{\mathrm{V} 600 \mathrm{E}}$ and wild-type KIT (upper). 


\section{DISCUSSION}

This study describes the purification of CTC from the peripheral blood of melanoma patients using immunomagnetic beads coated with HMW-MAA-specific antibodies followed by immunohistochemical laser dissection techniques. The BRAF and KIT genotypes of the isolated CTC were then analysed; the results showed that the genotypes of the CTC differed from those of the primary tumours and metastatic lesions. The method outlined in this study presents a new opportunity to characterise the genetic mutations expressed by spreading melanoma cells.

CTC represent a promising prognostic biomarker for melanoma recurrence or progression. Since subclinical, distant metastases occur during the early stages of melanoma development (Ossowski and Aguirre-Ghiso, 2010), detecting melanoma cells released from metastatic tumours may help to identify those melanoma patients at high risk of developing systemic metastatic disease. However, clinical detection of these cells is often extensively delayed after removal of the primary melanoma lesions.

CTC in the epithelial cancers are frequently isolated using immunomagnetic separation techniques incorporating antibodies against epithelial-specific antigens, such as EpCAM, BerEP4, and cytokeratins (Paterlini-Brechot and Benali, 2007; Krebs et al, 2010; Negin and Cohen, 2010; Riethdorf and Pantel, 2010). However, somewhat conflicting results have been published regarding the prognostic value of CTC, although it appears that increased CTC numbers are associated with more diffuse cancers, a higher risk of relapse, and a poor prognosis in breast, colon, and other epithelial cancers (Paterlini-Brechot and Benali, 2007; Krebs et al, 2010; Negin and Cohen, 2010; Riethdorf and Pantel, 2010). As epithelial-specific antibodies are of no use when attempting to isolate CTC from melanoma patients, CTC have been examined at the mRNA level using PCR-based methods. The presence of melanoma cell-specific mRNA seems to be associated with a poor outcome (Mellado et al, 1999; Palmieri et al, 1999; Pantel et al, 1999; Koyanagi et al, 2005); however, such approaches do not permit the genotypic or phenotypic characterisation of melanoma CTC. Therefore, cellular approaches to CTC detection were developed using immunomagnetic cell sorting or other methods (Ulmer et al, 2004; Galanzha et al, 2009; Kitago et al, 2009; De Giorgi et al, 2010; Suesskind et al, 2011). The HMW-MAA-specific mAbs have been used for the immunomagnetic separation of melanoma CTC (Ulmer et al, 2004; Kitago et al, 2009; Suesskind et al, 2011), but single step selection methods using HMW-MAA still result in blood cell contamination. The HMW-MAA ${ }^{+}, \mathrm{CD}_{4} 5^{-}$, MART-1/gp $100^{+}$cells are morphologically different from blood cells and show atypical features, which can be used to confirm that isolated HMW-MAA ${ }^{+}, \mathrm{CD}_{4}{ }^{-}$, MART-1/ gp $100^{+}$cells are, in fact, CTC. A potential drawback of this method is the low yield, which may be attributable to the immunomagneticnegative selection of $\mathrm{CD}^{+} 5^{+}$cells, since a partial loss of CTC was observed during that process in patients with colon cancer (Ausch et al, 2007). Further technical improvements regarding the isolation procedure should aim at improving this aspect.

There are several powerful examples of the application of CTC genotyping to targeted cancer therapy. In lung cancer, molecular analysis of the epidermal growth factor receptor gene in CTC provides important information regarding therapeutic response and prognosis (Maheswaran et al, 2008). The human epidermal growth factor receptor-2 (HER2) gene is examined in CTC from breast cancer patients because HER2 antagonists are available for therapy. However, the HER2 status of the CTC is sometimes different from that of the primary tumours and metastatic lesions (Wulfing et al, 2006; Pestrin et al, 2009; Flores et al, 2010). Furthermore, a subset of patients with HER2-negative primary tumours developed HER2positive CTC as the tumour progressed (Meng et al, 2004; Pestrin et al, 2009). Similarly, the results of the present study show that, although the BRAF genotype of the CTC was similar to that of the resected primary tumours, there were still some important mismatches. The KIT genotype showed the greatest variability between primary melanomas, lymph node metastases, and CTC. Since the features of CTC are not always concordant with those of other lesions, it is necessary to pay attention to the genotypes of both the primary/metastatic lesions and the CTC.

CTC from one patient (No. 5) showed three BRAF genotypes $\left(B R A F^{\mathrm{V} 600 \mathrm{E}}, B R A F^{\mathrm{V} 600 \mathrm{~K}}\right.$, and wild type). Analysis at the single cell level allowed further genetic dissection, as conventional sequencing techniques fail to detect minor mutations (Ellison et al, 2010). The polyclonal genotype implies that melanoma cells have heterogeneous features. It is noteworthy that oesophageal cancer cells disseminate to the bone marrow and lymph nodes at an early stage. Whole genome analysis at the single cell level showed that these disseminated tumour cells are genomically heterogeneous (Stoecklein et al, 2008). It is conceivable that, as in oesophageal cancer, heterogeneous melanoma cells may disseminate to various tissues at an early stage. BRAF genotyping from single melanoma cells showed heterogeneity within metastatic lesions and primary tumours (Lin et al, 2011). In the present study, $B R A F$ heterogeneity was also detected within metastatic melanomas through the analysis of DNA isolated from dozens of tumour cells. Intralesional heterogeneity within metastatic lesions is likely to cause mismatched genotypes between CTC and macrodissected metastatic lesions. The CTC features may reflect the cellular state of active melanoma cells migrating from metastatic lesions.

$B R A F$ heterogeneity has significant implications when using $R A F$ kinase inhibitors because, in contrast to $B R A F^{\mathrm{V} 600 \mathrm{E}}$ melanoma cells, $B R A F$ wild-type cells are resistant to (and may even be stimulated by) $R A F$ kinase inhibitors (Hatzivassiliou et al, 2010; Heidorn et al, 2010). Furthermore, most patients with BRAF V600E mutations develop secondary resistance and show subsequent disease progression. Based on the heterogeneity of melanoma cells, secondary resistance may be attributable to $B R A F$ heterogeneity. In this case, the number of wild-type BRAF CTC may alter after treatment with kinase inhibitors, and CTC analysis may help to identify the point at which cells 'escape', leading to resistance and relapse.

The CTC analysis also has potential benefits in terms of treating KIT mutant melanomas. Recent phase II clinical trials involving patients with metastatic melanoma harbouring KIT mutations reported significant clinical responses to imatinib in a subset of patients (Carvajal et al, 2011; Guo et al, 2011). However, tyrosine kinase inhibitors show little or no activity in melanoma cells harbouring wild-type KIT (Becker et al, 2007). In a particular case of melanoma with metastases in the lung and lymph nodes, imatinib treatment led to a rapid response in lung metastases harbouring the KIT $T^{\mathrm{V} 559 \mathrm{~A}}$ mutation, but no response in lymph node metastases without the mutation (Terheyden et al, 2010). Thus, mutation screening is critical if we are to identify those patients that may benefit from the kinase-targeted therapy.

The present study has several limitations. First, the number of melanomas examined was small. Second, PCR amplification from single CTC occasionally failed; melanoma cells may include substances that inhibit PCR. Further improvement of single cell PCR methods may eliminate this limitation. Third, the metastatic potential of CTC is not clear. Furthermore, we do not have data to allow us to examine the relationship between the results of CTC genotyping and clinical outcome. However, CTC may provide realtime information regarding cancers at the whole-body level. More work is necessary to develop methods for the isolation and analysis of CTC, but there is no doubt that the information provided by CTC will improve the ability of clinicians to predict responses to molecular-targeted therapies.

\section{ACKNOWLEDGEMENTS}

This study was supported by a Grant-in-Aid from the Ministry of Education, Culture, Sports, Science, and Technology of the 
Japanese government (YG, YK, MT, and RO); a Grant-in-Aid from the Ministry of Health, Labor, and Welfare of Japan; Grants-in-Aid for Scientific Research from the Japan Society for the Promotion of Science (YK and MT); and by the PHS grant R01 CA138188 (SF) awarded by the National Cancer Institute.

\section{REFERENCES}

Allard WJ, Matera J, Miller MC, Repollet M, Connelly MC, Rao C, Tibbe AG, Uhr JW, Terstappen LW (2004) Tumor cells circulate in the peripheral blood of all major carcinomas but not in healthy subjects or patients with nonmalignant diseases. Clin Cancer Res 10: 6897-6904

Ausch C, Dandachi N, Buxhofer-Ausch V, Balic M, Huber K, Bauernhofer T, Ogris E, Hinterberger W, Braun S, Schiessel R (2007) Immunomagnetic CD45 depletion does not improve cytokeratin 20 RT-PCR in colorectal cancer. Clin Chem Lab Med 45: 351-356

Becker JC, Brocker EB, Schadendorf D, Ugurel S (2007) Imatinib in melanoma: a selective treatment option based on KIT mutation status? J Clin Oncol 25: e9

Bustin SA, Benes V, Garson JA, Hellemans J, Huggett J, Kubista M, Mueller R, Nolan T, Pfaffl MW, Shipley GL, Vandesompele J, Wittwer CT (2009) The MIQE guidelines: minimum information for publication of quantitative real-time PCR experiments. Clin Chem 55: 611-622

Buttner C, Henz BM, Welker P, Sepp NT, Grabbe J (1998) Identification of activating c-kit mutations in adult-, but not in childhood-onset indolent mastocytosis: a possible explanation for divergent clinical behavior. J Invest Dermatol 111: 1227 - 1231

Campoli MR, Chang CC, Kageshita T, Wang X, McCarthy JB, Ferrone S (2004) Human high molecular weight-melanoma-associated antigen (HMW-MAA): a melanoma cell surface chondroitin sulfate proteoglycan (MSCP) with biological and clinical significance. Crit Rev Immunol 24: $267-296$

Carvajal RD, Antonescu CR, Wolchok JD, Chapman PB, Roman RA, Teitcher J, Panageas KS, Busam KJ, Chmielowski B, Lutzky J, Pavlick AC, Fusco A, Cane L, Takebe N, Vemula S, Bouvier N, Bastian BC, Schwartz GK (2011) KIT as a therapeutic target in metastatic melanoma. JAMA 305: $2327-2334$

Chapman PB, Hauschild A, Robert C, Haanen JB, Ascierto P, Larkin J, Dummer R, Garbe C, Testori A, Maio M, Hogg D, Lorigan P, Lebbe C, Jouary T, Schadendorf D, Ribas A, O’Day SJ, Sosman JA, Kirkwood JM, Eggermont AM, Dreno B, Nolop K, Li J, Nelson B, Hou J, Lee RJ, Flaherty KT, McArthur AG (2011) Improved survival with vemurafenib in melanoma with BRAF V600E mutation. N Engl J Med 364: 2507-2516

Curtin JA, Busam K, Pinkel D, Bastian BC (2006) Somatic activation of KIT in distinct subtypes of melanoma. J Clin Oncol 24: 4340-4346

Davies H, Bignell GR, Cox C, Stephens P, Edkins S, Clegg S, Teague J, Woffendin H, Garnett MJ, Bottomley W, Davis N, Dicks E, Ewing R, Floyd Y, Gray K, Hall S, Hawes R, Hughes J, Kosmidou V, Menzies A, Mould C, Parker A, Stevens C, Watt S, Hooper S, Wilson R, Jayatilake H, Gusterson BA, Cooper C, Shipley J, Hargrave D, Pritchard-Jones K, Maitland N, Chenevix-Trench G, Riggins GJ, Bigner DD, Palmieri G, Cossu A, Flanagan A, Nicholson A, Ho JW, Leung SY, Yuen ST, Weber BL, Seigler HF, Darrow TL, Paterson H, Marais R, Marshall CJ, Wooster R, Stratton MR, Futreal PA (2002) Mutations of the BRAF gene in human cancer. Nature 417: 949 - 954

De Giorgi V, Pinzani P, Salvianti F, Panelos J, Paglierani M, Janowska A, Grazzini M, Wechsler J, Orlando C, Santucci M, Lotti T, Pazzagli M, Massi D (2010) Application of a filtration- and isolation-by-size technique for the detection of circulating tumor cells in cutaneous melanoma. J Invest Dermatol 130: 2440-2447

Ellison G, Donald E, McWalter G, Knight L, Fletcher L, Sherwood J, Cantarini M, Orr M, Speake G (2010) A comparison of ARMS and DNA sequencing for mutation analysis in clinical biopsy samples. J Exp Clin Cancer Res 29: 132

Flaherty KT, Puzanov I, Kim KB, Ribas A, McArthur GA, Sosman JA, O’Dwyer PJ, Lee RJ, Grippo JF, Nolop K, Chapman PB (2010) Inhibition of mutated, activated BRAF in metastatic melanoma. $N$ Engl J Med 363: $809-819$

Flores LM, Kindelberger DW, Ligon AH, Capelletti M, Fiorentino M, Loda M, Cibas ES, Janne PA, Krop IE (2010) Improving the yield of circulating tumour cells facilitates molecular characterisation and recognition of

\section{Conflict of interest}

The authors declare no conflict of interest.

Supplementary Information accompanies the paper on British Journal of Cancer website (http://www.nature.com/bjc)

discordant HER2 amplification in breast cancer. Br J Cancer 102: 1495 1502

Galanzha EI, Shashkov EV, Spring PM, Suen JY, Zharov VP (2009) In vivo, noninvasive, label-free detection and eradication of circulating metastatic melanoma cells using two-color photoacoustic flow cytometry with a diode laser. Cancer Res 69: 7926-7934

Guo J, Si L, Kong Y, Flaherty KT, Xu X, Zhu Y, Corless CL, Li L, Li H, Sheng X, Cui C, Chi Z, Li S, Han M, Mao L, Lin X, Du N, Zhang X, Li J, Wang B, Qin S (2011) Phase II, open-label, single-arm trial of imatinib mesylate in patients with metastatic melanoma harboring c-Kit mutation or amplification. J Clin Oncol 29: 2904-2909

Hatzivassiliou G, Song K, Yen I, Brandhuber BJ, Anderson DJ, Alvarado R, Ludlam MJ, Stokoe D, Gloor SL, Vigers G, Morales T, Aliagas I, Liu B, Sideris S, Hoeflich KP, Jaiswal BS, Seshagiri S, Koeppen H, Belvin M, Friedman LS, Malek S (2010) RAF inhibitors prime wild-type RAF to activate the MAPK pathway and enhance growth. Nature 464: $431-435$

Heidorn SJ, Milagre C, Whittaker S, Nourry A, Niculescu-Duvas I, Dhomen N, Hussain J, Reis-Filho JS, Springer CJ, Pritchard C, Marais R (2010) Kinase-dead BRAF and oncogenic RAS cooperate to drive tumor progression through CRAF. Cell 140: 209-221

Hofmann UB, Kauczok-Vetter CS, Houben R, Becker JC (2009) Overexpression of the KIT/SCF in uveal melanoma does not translate into clinical efficacy of imatinib mesylate. Clin Cancer Res 15: 324-329

Kitago M, Koyanagi K, Nakamura T, Goto Y, Faries M, O’Day SJ, Morton DL, Ferrone S, Hoon DS (2009) mRNA expression and BRAF mutation in circulating melanoma cells isolated from peripheral blood with high molecular weight melanoma-associated antigen-specific monoclonal antibody beads. Clin Chem 55: 757-764

Koyanagi K, Kuo C, Nakagawa T, Mori T, Ueno H, Lorico Jr AR, Wang HJ, Hseuh E, O'Day SJ, Hoon DS (2005) Multimarker quantitative real-time PCR detection of circulating melanoma cells in peripheral blood: relation to disease stage in melanoma patients. Clin Chem 51: $981-988$

Krebs MG, Hou JM, Ward TH, Blackhall FH, Dive C (2010) Circulating tumour cells: their utility in cancer management and predicting outcomes. Ther Adv Med Oncol 2: $351-365$

Lanternier F, Cohen-Akenine A, Palmerini F, Feger F, Yang Y, Zermati Y, Barete S, Sans B, Baude C, Ghez D, Suarez F, Delarue R, Casassus P, Bodemer C, Catteau A, Soppelsa F, Hanssens K, Arock M, Sobol H, Fraitag S, Canioni D, Moussy A, Launay JM, Dubreuil P, Hermine O, Lortholary O (2008) Phenotypic and genotypic characteristics of mastocytosis according to the age of onset. PLoS One 3: e1906

Lin J, Goto Y, Murata H, Sakaizawa K, Uchiyama A, Saida T, Takata M (2011) Polyclonality of BRAF mutations in primary melanoma and the selection of mutant alleles during progression. $\mathrm{Br} J$ Cancer 104: $464-468$

Lin J, Takata M, Murata H, Goto Y, Kido K, Ferrone S, Saida T (2009) Polyclonality of BRAF mutations in acquired melanocytic nevi. J Natl Cancer Inst 101: 1423-1427

Maheswaran S, Sequist LV, Nagrath S, Ulkus L, Brannigan B, Collura CV, Inserra E, Diederichs S, Iafrate AJ, Bell DW, Digumarthy S, Muzikansky A, Irimia D, Settleman J, Tompkins RG, Lynch TJ, Toner M, Haber DA (2008) Detection of mutations in EGFR in circulating lung-cancer cells. $N$ Engl J Med 359: $366-377$

Mellado B, Gutierrez L, Castel T, Colomer D, Fontanillas M, Castro J, Estape J (1999) Prognostic significance of the detection of circulating malignant cells by reverse transcriptase-polymerase chain reaction in long-term clinically disease-free melanoma patients. Clin Cancer Res 5: 1843-1848

Meng S, Tripathy D, Shete S, Ashfaq R, Haley B, Perkins S, Beitsch P, Khan A, Euhus D, Osborne C, Frenkel E, Hoover S, Leitch M, Clifford E, Vitetta E, Morrison L, Herlyn D, Terstappen LW, Fleming T, Fehm T, Tucker T, Lane N, Wang J, Uhr J (2004) HER-2 gene amplification can be acquired as breast cancer progresses. Proc Natl Acad Sci USA 101: 9393-9398 
Mocellin S, Keilholz U, Rossi CR, Nitti D (2006) Circulating tumor cells: the 'leukemic phase' of solid cancers. Trends Mol Med 12: 130-139

Negin BP, Cohen SJ (2010) Circulating tumor cells in colorectal cancer: past, present, and future challenges. Curr Treat Options Oncol 11: $1-13$

Ossowski L, Aguirre-Ghiso JA (2010) Dormancy of metastatic melanoma. Pigment Cell Melanoma Res 23: 41-56

Palmieri G, Strazzullo M, Ascierto PA, Satriano SM, Daponte A, Castello G (1999) Polymerase chain reaction-based detection of circulating melanoma cells as an effective marker of tumor progression. Melanoma Cooperative Group. J Clin Oncol 17: 304-311

Pantel K, Cote RJ, Fodstad O (1999) Detection and clinical importance of micrometastatic disease. J Natl Cancer Inst 91: 1113-1124

Paterlini-Brechot P, Benali NL (2007) Circulating tumor cells (CTC) detection: clinical impact and future directions. Cancer Lett 253: $180-204$

Pestrin M, Bessi S, Galardi F, Truglia M, Biggeri A, Biagioni C, Cappadona S, Biganzoli L, Giannini A, Di Leo A (2009) Correlation of HER2 status between primary tumors and corresponding circulating tumor cells in advanced breast cancer patients. Breast Cancer Res Treat 118: $523-530$

Piyamongkol W, Bermudez MG, Harper JC, Wells D (2003) Detailed investigation of factors influencing amplification efficiency and allele drop-out in single cell PCR: implications for preimplantation genetic diagnosis. Mol Hum Reprod 9: 411-420

Platz A, Egyhazi S, Ringborg U, Hansson J (2008) Human cutaneous melanoma; a review of NRAS and BRAF mutation frequencies in relation to histogenetic subclass and body site. Mol Oncol 1: 395-405

Riethdorf S, Pantel K (2010) Advancing personalized cancer therapy by detection and characterization of circulating carcinoma cells. Ann NY Acad Sci 1210: 66-77
Romano E, Schwartz GK, Chapman PB, Wolchock JD, Carvajal RD (2011) Treatment implications of the emerging molecular classification system for melanoma. Lancet Oncol 12: 913-922

Stoecklein NH, Hosch SB, Bezler M, Stern F, Hartmann CH, Vay C, Siegmund A, Scheunemann P, Schurr P, Knoefel WT, Verde PE, Reichelt U, Erbersdobler A, Grau R, Ullrich A, Izbicki JR, Klein CA (2008) Direct genetic analysis of single disseminated cancer cells for prediction of outcome and therapy selection in esophageal cancer. Cancer Cell 13: $441-453$

Suesskind D, Ulmer A, Schiebel U, Fierlbeck G, Spitzer B, Spitzer MS, BartzSchmidt KU, Grisanti S (2011) Circulating melanoma cells in peripheral blood of patients with uveal melanoma before and after different therapies and association with prognostic parameters: a pilot study. Acta Ophthalmol 89: 17-24

Tarn C, Merkel E, Canutescu AA, Shen W, Skorobogatko Y, Heslin MJ, Eisenberg B, Birbe R, Patchefsky A, Dunbrack R, Arnoletti JP, von Mehren M, Godwin AK (2005) Analysis of KIT mutations in sporadic and familial gastrointestinal stromal tumors: therapeutic implications through protein modeling. Clin Cancer Res 11: 3668-3677

Terheyden P, Houben R, Pajouh P, Thorns C, Zillikens D, Becker JC (2010) Response to imatinib mesylate depends on the presence of the V559Amutated KIT oncogene. J Invest Dermatol 130: 314-316

Ulmer A, Schmidt-Kittler O, Fischer J, Ellwanger U, Rassner G, Riethmuller G, Fierlbeck G, Klein CA (2004) Immunomagnetic enrichment, genomic characterization, and prognostic impact of circulating melanoma cells. Clin Cancer Res 10: $531-537$

Woodman SE, Davies MA (2010) Targeting KIT in melanoma: a paradigm of molecular medicine and targeted therapeutics. Biochem Pharmacol 80: $568-574$

Wulfing P, Borchard J, Buerger H, Heidl S, Zanker KS, Kiesel L, Brandt B (2006) HER2-positive circulating tumor cells indicate poor clinical outcome in stage I to III breast cancer patients. Clin Cancer Res 12: 1715-1720

This work is published under the standard license to publish agreement. After 12 months the work will become freely available and the license terms will switch to a Creative Commons Attribution-NonCommercial-Share Alike 3.0 Unported License. 